pp. $27-36$

\author{
Mirosław Łukasz RÓG \\ ORCID: 0000-0002-9638-4509 \\ Uniwersytet Marii Curie-Skłodowskiej \\ w Lublinie
}

\title{
Problemy w nauczaniu i uczeniu się języka angielskiego w klasach I-III szkoły podstawowej w opiniach nauczycieli
}

\begin{abstract}
Problems in Teaching and Learning English in Grades 1-3 of the Primary School in the Opinions of Teachers

The aim of this study was to show problems in teaching and learning English in grades 1-3 of the primary school in the opinions of teachers. The research included 15 teachers working in the Lubelskie and Świętokrzyskie Voivodeships, Poland. The results show that children learning English have the greatest problems with grammar, followed by reading and writing. In the first stage of learning, teachers should focus on pronunciation and speaking. Teachers have the main problems with the choosing of appropriate teaching methods, which is the result of a lack of adequate preparation during studies.
\end{abstract}

Keywords: foreign language learning problems, difficulties of teaching English language

Słowa kluczowe: problemy w uczeniu się języka obcego, trudności nauczania języka angielskiego

\section{Wprowadzenie}

Współcześnie, w świecie globalizacji, posługiwanie się językami obcymi, a przede wszystkim angielskim, uważane jest za rzecz naturalną. Wzmożoną potrzebę poznawania i komunikowania się w językach obcych dostrzegły już instytucje europejskie w latach dziewięćdziesiątych ubiegłego stulecia, co wiązało się z silnymi tendencjami integracyjnymi państw Europy oraz promowaniem idei wielokulturowości. W pierwszych latach XXI w. Komisja Europejska wraz z Radą Europy zaczęły kłaść szczególny nacisk na naukę dwóch języków obcych od wczesnych lat szkolnych. W tych państwach, w których uczniowie zaczynali naukę języka obcego mniej więcej na drugim etapie szkoły podstawowej, zostały podjęte działania, aby pierwszy język obcy był nauczany w pierwszych latach edukacji szkolnej (Siek-Piskozub, 2009, s. 9). W Polsce, zgodnie z obowiązują- 
cą podstawą programową, uczniowie w klasach I-VI szkoły podstawowej obowiązkowo uczą się jednego języka obcego nowożytnego, w kolejnych klasach zaś - dwóch języków obcych (DzU, 2017, poz. 356). Wprowadzenie na wczesnym edukacji etapie nauczania języka obcego ma wiele pozytywnych aspektów. W literaturze podkreśla się, że nabywanie przez dzieci umiejętności posługiwania się językiem obcym jest podobne do akwizycji języka ojczystego, gdyż nie mają one wypracowanych i utrwalonych struktur oraz schematów językowych. Uczenie odbywa się więc w sposób naturalny. Ponadto dzieci lepiej przyswajają wymowę, a ich intonacja zbliża się do rodzimych użytkowników języka. Niemałe znaczenie ma to, że wcześniejsze rozpoczęcie nauki owocuje w przyszłości. Pozwala ono bowiem ugruntować wiedzę i umiejętności językowe oraz wytwarza predyspozycję do uczenia się języków obcych przez całe życie. Trzeba też podkreślić, że wczesna nauka języka obcego otwiera dzieci na wielojęzyczność oraz bliższe zaznajomienie się z innymi kulturami. Poznanie kultury, zwyczajów innych narodów przyczynia się do bogatszego rozwoju społecznego, co przekłada się na pozytywne nastawienie do różnorodności kulturowej, poszanowanie odmienności, zrozumienie dla innych itd. (Szpotowicz, 2015, s. 17-18).

$\mathrm{Z}$ powyższych rozważań wynika, że podjęcie nauki we wczesnym okresie edukacji jest ważne i wpływa na rozwój młodego człowieka w wielu dziedzinach. Literatura obfituje $\mathrm{w}$ artykuły podejmujące kwestię nauczania języków obcych z punktu widzenia metodyki. Można jednak zauważyć niedostatek opracowań, które odnoszą się do problemów uczenia się i nauczania języków obcych, w tym przypadku języka angielskiego, z perspektywy nauczycieli praktyków. Niniejszy tekst ma więc wypełnić tę lukę.

W przekonaniu autora problemy związane $z$ uczeniem się i nauczaniem języka angielskiego dzieci w klasach I-III można sprowadzić do trzech podstawowych zagadnień:

- umiejętności nabywania języka w kontekście okresu rozwojowego $\mathrm{z}$ uwzględnieniem predyspozycji indywidualnych dziecka, w tym zaburzeń;

- kompetencji nauczyciela;

— specyfiki języka angielskiego i różnic w stosunku do języka polskiego.

Jeśli chodzi o pierwsze $\mathrm{z}$ wymienionych zagadnień, to żeby zidentyfikować problemy z uczeniem się języka obcego, należy bliżej scharakteryzować cechy rozwoju dzieci w wieku 7-9 lat, przynajmniej te, które mogą powodować pewne trudności w nauce. Wiek ten zaliczany jest do tzw. okresu wczesnoszkolnego, trwającego między 7 a 12 rokiem życia. Dziecko w tym czasie odczuwa dużą potrzebę ruchu, co związane jest z dalszym rozwojem motoryki dużej. Mięśnie większe rozwijają się szybciej, dzieci są więc w stanie wykonywać ruchy silne, zamaszyste, a zarazem nieodpowiednie do tempa działania. Mięśnie małe rozwijają się natomiast wolniej, a więc wykonywanie precyzyjnych ruchów manualnych jest w tym okresie dla dzieci męczące. Może to przysparzać problemów 
z odwzorowywaniem liter, tempem pisania, rysowaniem itd., ogólnie - z motoryką małą (Becelewska, 2006, s. 181-184).

Proces myślenia dziecka oparty jest na operacjach konkretnych, na tej podstawie odbywa się wnioskowanie. Dziecko zaczyna dostrzegać relacje zachodzące pomiędzy obiektami i zbiorami. $Z$ trudnością przychodzi mu wyciąganie wniosków, kiedy odwołuje się do wyobraźni, dopiero około 8. roku życia pojawia się myślenie przyczynowo-skutkowe, w którym pierwszorzędną rolę odgrywa logika. Rozwijają się inne funkcje sfery intelektualnej, do których zalicza się analizę i syntezę wzrokową oraz słuchową. Jeśli procesy te zostaną zaburzone, mogą wystąpić problemy $\mathrm{z}$ opanowaniem umiejętności czytania i pisania (Wieszczerzyńska, 2009, s. 40-41).

Rozwojowi podlega także pamięć, w szczególności jej zakres, trwałość i szybkość zapamiętywania. Dziecko reprezentuje dobrą pamięć mechaniczną, a pamięć logiczna dopiero się kształtuje pod wpływem oddziaływań edukacyjnych. Wszystko to, co dziecko interesuje, zapamiętywane jest więc bardzo szybko, ale wychwytywanie i zapamiętywanie związków logicznych występujących w tekście jest bardzo trudne. Podstawowym problemem w zapamiętywaniu jest brak wprawy w uczeniu się. W związku z tym rola nauczyciela sprowadza się do nauczenia sposobu uczenia się, aby rozwinąć pamięć logiczną (Becelewska, 2006, s. 183).

Omawiając problemy w uczeniu się języka, trzeba także zwrócić uwagę na indywidualne cechy dziecka. Każde dziecko jest inne. Różnice można dostrzec m.in. $\mathrm{w}$ inteligencji, preferowanych stylach uczenia się, koncentracji uwagi. Jeśli chodzi o inteligencję, to można powiedzieć, że nie jest ona jednorodna i taka sama u wszystkich dzieci. Wyróżnia się kilka typów inteligencji, które pojawiają się u dzieci z różnym nasileniem i w różnych kombinacjach. Wśród nich wymienia się: matematyczną, muzyczną, ruchową, wizualno-przestrzenną, refleksyjną, interpersonalną, przyrodniczą i oczywiście lingwistyczną. Dzieci, u których przeważa ta ostatnia, będą wykazywać zdecydowanie mniejsze trudności w nauce języka. Dzieci mogą preferować również odmienne style uczenia się. Dla jednych będzie liczyć się dokładność, głębsza analiza, inne będą podchodzić do nauki w sposób impulsywny. Sposób percepcji informacji też nie jest bez znaczenia, niektóre wolą słuchać, inne wolą, gdy dociera ona do nich wizualnie (Krzemińska, 2009, s. 31-32). Kolejna kwestia dotyczy zdolności skupienia uwagi dowolnej. Czas koncentrowania się na wykonywaniu danej czynności determinowany jest głównie cecha$\mathrm{mi}$ temperamentu. Występują również różnice w stopniu podzielności lub przerzutności uwagi. Dotychczasowe obserwacje wskazują, że stopień umiejętności dowolnego skupienia uwagi bezpośrednio przekłada się na osiągane wyniki w nauce. Słabsze wyniki osiągają ci uczniowie, którzy zbyt krótko lub zbyt długo skupiają się na zadaniu, nie stosują strategii umysłowych albo mobilizują się w mniejszym stopniu (Stefańska-Klar, 2000, s. 133-134). 
Wpływ na naukę mają również różne całościowe zaburzenia rozwojowe, zaburzenia mowy czy zaburzenia rozwoju umiejętności szkolnych. W szeroko ujętym sensie zaburzenia będą obejmować więc np.: spektrum autyzmu, ADHD, afazję, dysgrafię, dysleksję, dysortografię $\mathrm{i}$ in. Jest to jednak zagadnienie bardziej złożone, wymagające szerszego opracowania każdego $z$ tych problemów oddzielnie, dlatego tu zostało tylko zasygnalizowane.

Niezwykle istotny wpływ na proces nauczania i uczenia się języka angielskiego mają kompetencje i kwalifikacje nauczycieli. Mała biegłość w posługiwaniu się językiem, nieznajomość psychiki dziecka we wczesnym okresie szkolnym, niedostateczne przygotowanie metodyczne i dydaktyczne moga zdecydowanie zaburzać obydwa procesy. Przez kompetencje należy rozumieć „udowodnioną zdolność stosowania wiedzy, umiejętności i predyspozycji osobistych, społecznych lub metodologicznych ukazywaną w pracy lub nauce oraz w karierze zawodowej i osobistej" (Kędzierska, Potyrała, 2015, s. 122). Kompetencje są więc pod względem zakresu bardzo szerokim pojęciem i obejmują wiele predyspozycji, które czynią nauczyciela mistrzem w swoim zawodzie. Kompetencje to nie tylko kwalifikacje, kompleksowa i specjalistyczna wiedza, ale również zestaw postaw, poglądów, zainteresowań itd. (Ir, 2016, s. 53).

W przypadku nauczyciela języka obcego, w kontekście nauczania, trzy grupy kompetencji wydają się najbardziej istotne, a więc: psychologiczno-pedagogiczne, dydaktyczno-metodyczne oraz językowe (Jakosz, 2015, s. 96). Pierwsze $\mathrm{z}$ wymienionych dotyczą posiadania określonej wiedzy psychologicznej i pedagogicznej oraz jej praktycznego zastosowania. Nauczyciel musi znać pewne prawidłowości rozwojowe uczniów, które następnie wykorzystuje w procesie nauczania i wychowania (Strykowski, 2005, s. 19-20). Nauczyciele języków obcych nierzadko starają się uczyć dzieci w sposób podobny do tego, w jaki pracują $\mathrm{z}$ młodzieżą lub osobami dorosłymi. Kiedy nie widzą oczekiwanych efektów, czują dyskomfort i w końcu dochodzą do wniosku, że nauka języka obcego na pierwszym etapie edukacji w ogóle pozbawiona jest podstaw. Niektórzy z nich nie uświadamiają sobie, że nauczając dzieci, należy uwzględniać ich możliwości oraz dostosować do nich metody i treści nauczania (Jakosz, 2015, s. 96). Kompetencje dydaktyczno-metodyczne dotyczą umiejętności posługiwania się metodami oraz środkami dydaktycznymi. Przy wyborze metody nauczyciel powinien kierować się, jak już zaznaczono, wiekiem uczniów, ale też celem zajęć oraz charakterem materiału nauczania. Kompetencje te obejmują cały warsztat pracy, w jaki pedagog został wyposażony w trakcie studiów (Taraszkiewicz, 2001, s. 175). Kompetencje językowe $\mathrm{w}$ nauczaniu języka obcego są z kolei uważane za jedne $\mathrm{z}$ najważniejszych, zwłaszcza w pierwszym okresie edukacji uczniów. Nauczyciel powinien w sposób swobodny i nieskrępowany posługiwać się językiem angielskim, bez 
popełniania błędów (Jakosz, 2015, s. 98). Bardzo ważna jest prawidłowa wymowa i intonacja, albowiem dzieci w klasach I-III uczą się języka głównie ze słuchu, nie mogąc $w$ pełni korzystać $z$ tekstów pisanych.

Ostatnia grupa trudności w uczeniu się języka angielskiego odnosi się do jego specyfiki i różnic między nim a językiem polskim. Różnice te pojawiają się na wielu płaszczyznach. Jeśli chodzi o zakres nauczania języka angielskiego w klasach I-III, to wydaje się, że można je ująć następująco:

- składniowe - język polski jest językiem fleksyjnym (syntetycznym), angielski zaś pozycyjnym (amorficznym), w którym z reguły musi być zachowana odpowiednia kolejność poszczególnych części zdania (podstawowy szyk: podmiot + orzeczenie + dopełnienie);

- fonetyczne - odmienna artykulacji dźwięków występująca w obu językach (dotyczy głosek);

— „stricte gramatyczne” - przedimki, różne formy czasu teraźniejszego itd., które nie pojawiają się w języku polskim;

- leksykalne: idiomy, czasowniki frazowe;

- mniejsza zgodność postaci fonicznej słów z postacią graficzną, niż to ma miejsce w języku polskimu.

\section{Materiał i metody badań}

Celem poznania trudności $\mathrm{w}$ uczeniu się i nauczaniu języka angielskiego $\mathrm{w}$ klasach I-III z perspektywy nauczyciela przeprowadzono wywiad pogłębiony z 15 nauczycielami, którzy prowadzili zajęcia na tym poziomie edukacji. Dobór próby opierał się na metodzie kuli śnieżnej.

Badani nauczyciele pracowali $\mathrm{w}$ szkołach na terenie województw świętokrzyskiego i lubelskiego, zarówno w miastach, jak i na wsiach. Bliższą charakterystykę badanych przedstawiono w tabeli 1 .

Wśród badanych było 13 kobiet i 2 mężczyzn. Średnia wieku badanych wyniosła 36,3 lat, a staż pracy - 9,3 lat. Wszyscy badani legitymowali się wykształceniem wyższym. Większość ukończyła studia w zakresie filologii angielskiej, dwie osoby - w zakresie lingwistyki stosowanej, a jedna nauczycielka miała dyplom ukończenia studiów w zakresie pedagogiki przedszkolnej i wczesnoszkolnej, podparte certyfikatem CAE (Certificate in Advanced English).

\section{Wyniki i ich omówienie}

Wywiad $\mathrm{z}$ nauczycielami pozwolił na wyznaczenie kilku istotnych płaszczyzn związanych z problemami nauczania i uczeniem się języka angielskiego. Na- 
Tabela 1. Charakterystyka grupy badanej

\begin{tabular}{|c|l|c|c|l|}
\hline Lp. & Płeć & Wiek & $\begin{array}{c}\text { Staż pracy } \\
\text { w szkole }\end{array}$ & Wykształcenie \\
\hline 1 & Kobieta & 25 & 1 & Filologia angielska (licencjat) \\
\hline 2 & Kobieta & 26 & 1 & Filologia angielska (magisterium) \\
\hline 3 & Kobieta & 27 & 2 & Filologia angielska (licencjat) \\
\hline 4 & Kobieta & 28 & 3 & Filologia angielska (licencjat) \\
\hline 5 & Kobieta & 29 & 3 & Lingwistyka stosowana (magisterium) \\
\hline 6 & Kobieta & 33 & 5 & Filologia angielska (magisterium) \\
\hline 7 & Kobieta & 34 & 8 & $\begin{array}{l}\text { Pedagogika przedszkolna i wczesnoszkolna } \\
\text { (magisterium) + certyfikat CAE }\end{array}$ \\
\hline 8 & Kobieta & 34 & 7 & Lingwistyka stosowana (magisterium) \\
\hline 9 & Kobieta & 37 & 11 & Filologia angielska (magisterium) \\
\hline 10 & Mężczyzna & 38 & 12 & Filologia angielska (magisterium) \\
\hline 11 & Kobieta & 38 & 9 & Filologia angielska (magisterium) \\
\hline 12 & Mężczyzna & 44 & 13 & Filologia angielska (magisterium) \\
\hline 13 & Kobieta & 48 & 14 & Filologia angielska (magisterium) \\
\hline 14 & Kobieta & 51 & 25 & Filologia angielska (magisterium) \\
\hline 15 & Kobieta & 53 & 26 & Filologia angielska (magisterium) \\
\hline
\end{tabular}

uczyciele śmiało wskazywali, że trudności te leżą zarówno po stronie ucznia, jego otoczenia, jak i ich samych.

\section{Problemy nauczania języka angielskiego}

Wśród problemów związanych z nauczaniem nauczyciele na pierwszym miejscu wymieniali nieodpowiednie zachowania uczniów. Wypowiedzi nauczycieli w tym kontekście odnosiły się nie tyle do problemów z nauczaniem języka, ale raczej do nauczania dzieci w ogóle:

Największym problemem dla mnie jest brak chęci wspótpracy uczniów na lekcjach. Nie mówię o wszystkich oczywiście. Dzieci w większości sa urocze, ale niektóre nie chca wykonywać poleceń, np.: „Fa nie będę rysowat”. Kiedy pytam: „dlaczego?”. „Bo nie chcę”. Trudno mi wtedy wtaściwie reagować. Mówię: „spójrz jak Lenka tadnie narysowata”. W odpowiedzi styszę: „fa nie będę”. [...] Niektóre nie lubia śpiewać, kolorować. To mi dezorganizuje prace, gdyż inne dzieci zaczynaja podobnie reagować $(6)^{1}$.

\footnotetext{
${ }^{1}$ Liczbą w nawiasie oznaczono poszczególnych nauczycieli zgodnie z listą w tabeli 1 .
} 
Dzieci, najbardziej te z klas pierwszych, sa strasznie ruchliwe, wszędzie ich petno, bardzo szybko sie nudza, nie sa przyzwyczajone do nauki, sytuacja sie zmienia dopiero w starszych klasach. Caty czas trzeba zapewniać im jakaśs rozrywkę, a to czasami jest dla mnie męczace (3).

Mnie jako mężczyźnie trudno się pracuje z dziećmi w klasach najmłodszych. Trudno mi nieraz przewidzieć ich zachowania. Najlepiej, gdy zapewni się im dużo zabawy. [...] Sa sytuacje, które mnie krępuja, dzieciaki podbiegaja, przytulaja sie, a wie Pan, jakie teraz sa czasy. Wiem, że tak okazuja swoja życzliwość, ale nie rozumieja, że tak nie wypada (10).

Niektórzy uczniowie notorycznie nie odrabiaja prac domowych. Trudno mi to od nich wyegzekwować, a rozmowy z rodzicami nie przynosza zadowalajacych efektów. Festem zdania, że praca domowa ma stużyć przede wszystkim utrwaleniu treści, które byty omawiane na lekcjach. Feśli dziecko nie powtórzy w domu, nie utrwali, to z pewnością nie zapamięta. To raczej nie wina dziecka, ale rodziców, którzy nie potrafia tego dopilnować (14).

Ważnym zagadnieniem, które poruszali badani nauczyciele, była trudność w doborze odpowiednich metod nauczania. Zaznaczali, że jest to głównie wynikiem braku odpowiedniego przygotowania w ramach studiów. Niektórzy wskazywali, iż stosowanie sprawdzonych metod okazuje się niełatwe, gdyż w klasie jest wielu uczniów i nie dla każdego dana metoda jest skuteczna, a nie ma jednej, uniwersalnej. Oto wybrane wypowiedzi:

Pewna trudność w uczeniu sprawia mi to, że na studiach było bardzo mato o tym, w jaki sposób uczyć małe dzieci. Czytam o różnych metodach, $i$ taka, $i$ inna jest zachwalana, a ja się w tym gubię. W ramach praktyk miałam zajęcia $i$ hospitacje w szkole podstawowej, ale w starszych klasach, a tam to juz jest inna bajka. Robię więc na „czuja”, tak jak potrafie najlepiej (5).

Oczywiście, że sa trudności pod względem metodycznym. Nikt mi wtaściwie nie pokazat, jak pracuje się z dziećmi w klasach początkowych. Może dlatego, że jak studiowatam, to jeszcze nie byto obowiazku nauki języków obcych w szkołach podstawowych dla matych dzieci. Wszystkiego ucze się sama (9).

Ze stosowaniem metod jest o tyle problem, że niektórzy uczniowie sa wzrokowcami, inni stuchowcami, trudno się wcisnąć, dopasować. Fa przykładowo jestem wzrokowcem, obraz do mnie lepiej przemawia, więc wydaje mi się, że dużą wage przykładam do ćwiczeń opartych na wzroku. Łącze jednak różne metody, by oddziatywać na wszystkie zmysty dziecka. [...] Musi być miejsce na wszystkie elementy ważne w nauce języka: stuchanie, mówienie, pisanie, czytanie (6).

Bardzo istotne jest to, że nauczyciele za jedną z trudności nauczania języka angielskiego uznali niedostosowanie treści podręczników do możliwości dziecka. Podkreślali w tym kontekście, że dzieci mają braki w edukacji polonistycznej, a to utrudnia pracę nad treściami gramatycznymi:

Feśli chodzi o podręczniki [...], to ja uczę z podręczników ... [tu pada nazwa wydawnictwa], to sq dobre podręczniki, moim zdaniem, a w szkole pracuje już 12 lat, więc mam porównanie, ale materiat w klasie drugiej jest „kosmiczny”. Wchodzi bardzo dużo gramatyki i mam problemy z wyjaśnieniem zasad, bo dzieciaki nie rozumieja, co to jest czasownik, rzeczownik, przynajmniej takie mam doświadczenie. Fa musze thumaczyć, a to chyba nie jest moja rola. Nie wiem, jaki musza mieć zakres wiedzy $z$ polskiej gramatyki, bo się tym nie interesowatem, jest tu jakiś rozdźwięk (10). 
Mamy teraz bardzo ciekawe podręczniki, bogato ilustrowane, kolorowe, to z pewnościa ułatwia naukę. fednak nie jestem przekonana, czy ćwiczeń gramatycznych nie jest za dużo. Spokojnie można by to zostawić na później. Festem za tym, a nie jestem odosobniona, bo znam zdanie moich koleżanek, żeby raczej skupiać się na wymowie, rozumieniu ze stuchu, mówieniu. To jest istota nauki języka, na gramatykę, pisanie i czytanie przyjdzie czas (15).

Nauczyciele patrzyli na trudności związane z nauczaniem języka również pod kątem oferowanych im przez szkołę pomocy dydaktycznych. Niektórzy wprost twierdzili, że niektórych środków dydaktycznych nie ma na wyposażeniu szkoły:

Dużym problemem dla mnie w nauczaniu jest to, że nie mam w klasie telewizora, tablicy multimedialnej. WXXI wieku to chyba powinna być norma, ale cóż, ucze w małej wiejskiej szkole, więc chyba nie wypada mi narzekać (1).

Utrudnieniem z pewnościa jest brak nowoczesnych technologii. Na lekcjach korzystam z prywatnego laptopa, podtaczam do niego gtośniki, inaczej trudno byłoby coś ustyszeć. Obejrzeć krótka bajkę lub filmik to jest naprawdę wyzwanie. Dużo czasu poświęcam przygotowaniu różnych plansz i innych materiatów, aby starać się kompensować te niedogodności (8).

\section{Problemy uczenia się języka angielskiego}

W przytoczonych wypowiedziach można było dostrzec niektóre problemy pojawiające się w uczeniu się przez dzieci języka angielskiego (np. problemy ze zrozumieniem gramatyki). Niemniej warto bliżej przyjrzeć się innym wypowiedziom, które lepiej naświetlą to zjawisko.

Badani podkreślali, że problemy w uczeniu się języka zależą w dużym stopniu od wieku dziecka, przede wszystkim w zakresie pisania, czytania i wymowy:

Występują różne problemy u dzieci. $Z$ moich obserwacji wynika, że pierwszakom najtrudniej jest z pisaniem i czytaniem, bo myla litery. Pisza bardzo niezgrabnie, powoli. Nawet jeśli zapisze jakieś stówko na tablicy, to gdy uczniowie je przepisuja, potrafia popetnić btad. W klasie III, w której powinni już tworzyć dtuższe wypowiedzi, z trudem im to przychodzi (13).

Mam niewielkie doświadczenie, musze to przyznać, $i$ nie udato mi się jeszcze dużo zaobserwować. [...] Moi uczniowie maja poważne trudności z pisownia, nie tylko z angielska, ale i polska. Najwięcej uwagi musze poświęcić dzieciom z I klasy. O! W nie to faktycznie trzeba włożyć wiele wysitku (2).

Straszne problemy uczniowie młodsi mają z czytaniem i pisaniem. Najprościej mówiąc, pisza jak chca, a czytaja, jak widza. Doskonale ich rozumiem, nie sa jeszcze w stanie tych wszystkich niuansów pojąć. Trudności maja z zapisem polskich stówek, a co dopiero angielskich. „C” to „c”, nieważne, że $w$ angielskim „c”, jeśli nie występuje w sąsiedztwie innej spótgłoski ( $j a k$ „h”, czy „k”), trzeba wymówić jako $/ s / l u b / k /(12)$.

Kolejny problem, który sugerowali nauczyciele, to odbiór komunikatu ustnego, mówionego. Badani podkreślali, że dzieci potrafią wyłapać znaczenie wy- 
powiedzi z kontekstu, ale zrozumienie poszczególnych słów przychodzi im o wiele trudniej. $Z$ tego też względu nauczyciele starają się mówić bardzo wyraźnie, wręcz zniekształcają wymowę, aby zostać zrozumianymi:

Moi uczniowie maja problemy z tym, co do nich mówię, nie chodzi mi tu o formuly grzecznościowe czy też wydawane krótkie polecenia, jak „sit down”, „be quiet”, to sa w stanie zrozumieć. Feśli zaczynam mówić bardziej rozbudowanymi zdaniami, to tak dziwnie na mnie patrzą, jakby mnie w ogóle nie styszaty, nie rozumiaty. Kiedy to, co mówie podpieram gestami, mimika, to wtedy świetnie wyłapuja z kontekstu, co mam na myśli (11).

Uczniowie w najmłodszych klasach mają trudności w rozumieniu stów ze stuchu. Moim zdaniem to sie pojawia wtedy, gdy musza zestawić wymowe stówka z pisownia. Przyktadowo przeczenie „aren't”, wymawia się /a:nt/, ale gdy tak powiem, to dzieci myśla o mrówce albo o cioci², dlatego mówię /a:rant/, żeby wiedziaty, o co mi chodzi (4).

Często mam wrażenie, że dzieci nie rozumieja moich wypowiedzi, staram się wówczas powtórzyć bardzo wolno, jak zauważe, ż i to nie pomaga, to mówie po polsku, a potem znów to samo po angielsku. W III klasie zapisuje nieraz to, co powiedziałam, na tablicy, to im pomaga zrozumieć (15).

\section{Wnioski końcowe}

Zarówno przegląd piśmiennictwa, jak i badania pozwalają na sformułowanie kilka ważnych, a zarazem praktycznych wniosków mogących służyć jako przyczynek do dalszych badań nad problemami nauczania i uczenia się języka angielskiego w klasach I-III szkoły podstawowej, a także do ich rozwiązywania:

1. Na pierwszym etapie nauczania języka angielskiego (jak można mniemać, również każdego języka obcego) najpierw należy się skupić na ćwiczeniu wymowy poszczególnych głosek, rozumieniu ze słuchu, tworzeniu przez uczniów krótkich wypowiedzi ustnych, a w dalszej kolejności na pisaniu, czytaniu, a przede wszystkim gramatyce.

2. Problemy w nauczaniu i uczeniu się języka angielskiego w dużej mierze zależą od możliwości przyswajania wiedzy przez uczniów (związanych z okresem rozwoju) oraz kompetencji nauczyciela. Nauczyciel powinien być przygotowany nie tylko pod względem językowym, ale też psychologiczno-pedagogicznym, aby dostosować treści nauczania do możliwości dzieci.

3. Należy zapewnić nauczycielom odpowiednie warunki nauczania języka obcego (dostęp do wszelkich pomocy dydaktycznych wspomagających rozwój dziecka i nabywanie języka angielskiego).

4. Przyszli nauczyciele (głównie neofilolodzy) powinni w ramach studiów mieć zapewniony dostęp do szerokiej wiedzy na temat nauczania dzieci w przedszkolach i w klasach I-III szkoły podstawowej.

${ }^{2}$ Skrót aren't (od are not) jest homofonem i wymawia się go identycznie, jak słowa „ciocia” (aunt) lub „mrówka” (ant), mające inną pisownię. 
5. Nauczyciele powinni w trakcie zajęć zachować prawidłową wymowę angielską, nie jest dopuszczalna hiperpoprawność, gdyż u uczniów wieku 7-9 lat nie zakończył się jeszcze proces lateralizacji. Prawidłowa i naturalna wymowa zapewnia nabycie umiejętności wymawiania dźwięków w sposób zbliżony do rodzimych użytkowników języka, którego dzieci się uczą.

\section{Bibliografia}

Becelewska, D. (2006). Repetytorium z rozwoju cztowieka. Jelenia Góra: PWSZ.

Ir, E. (2016). Nauczyciel w kontekście zmian spotecznych. „Pedagogika Przedszkolna i Wczesnoszkolna", 4, nr 1 (7), s. 51-56.

Jakosz, M. (2015). Specyficzne kwalifikacje nauczycieli przedszkolnych $i$ wczesnoszkolnych do nauczania języków obcych metoda narracyjna. W: J. Iluk (red.), Nauczanie języków obcych w przedszkolu i na etapie wczesnoszkolnym na przykładzie języka niemieckiego. Podstawa programowa - zatożenia teoretyczne - zasady nauczania - efekty — kompetencje nauczycieli — opinie. Katowice: Wyd. UŚ, s. 95-108.

Kędzierska, B., Potyrała, K. (2015). Ksztattowanie i doskonalenie nauczycieli w globalizującym sie spoteczeństwie. „Rocznik Lubuski”, 41, cz. 2, s. 117-130.

Krzemińska, D. (2009). Wczesne rozpoczynanie nauki języków. W: D. Sikora-Banisk (red.), Wczesnoszkolne nauczanie języków obcych. Zarys teorii i praktyki. Warszawa: Centralny Ośrodek Doskonalenia Nauczycieli, s. 20-39.

Rozporządzenie Ministra Edukacji Narodowej z dnia 14 lutego 2017 r. w sprawie podstawy programowej wychowania przedszkolnego oraz podstawy programowej kształcenia ogólnego dla szkoły podstawowej, w tym dla uczniów z niepełnosprawnością intelektualną w stopniu umiarkowanym lub znacznym, kształcenia ogólnego dla branżowej szkoły I stopnia, kształcenia ogólnego dla szkoły specjalnej przysposabiającej do pracy oraz kształcenia ogólnego dla szkoły policealnej. DzU, 2017, poz. 356.

Siek-Piskozub, T. (2009). Nauczanie języków obcych dzieci w wieku wczesnoszkolnym - wyzwania i problemy. W: D. Sikora-Banisk (red.), Wczesnoszkolne nauczanie języków obcych. Zarys teorii i praktyki. Warszawa: Centralny Ośrodek Doskonalenia Nauczycieli, s. 9-19.

Stefańska-Klar, R. (2000). Późne dzieciństwo. Młodszy wiek szkolny. W: B. Charwas-Napierała, J. Trempała (red.), Psychologia rozwoju cztowieka. T. II.. Charakterystyka okresów życia cztowieka. Warszawa: PWN, s. 130-162.

Strykowski, W. (2005). Kompetencje wspótczesnego nauczyciela. „Neodidagmata”, nr 27-28, s. 15-28.

Szpotowicz, M. (2015). Nauka języka obcego dla wszystkich przedszkolaków. „Języki Obce w Szkole”, nr 1, s. 17-22.

Taraszkiewicz, M. (2001). Fak uczyć jeszcze lepiej! Szkoła petna ludzi. Poznań: Arka.

Wieszczeczyńska E. (2009). Psychorozwojowe uwarunkowania wczesnej edukacji językowej. W: D. Sikora-Banisk (red.), Wczesnoszkolne nauczanie języków obcych. Zarys teorii i praktyki. Warszawa: Centralny Ośrodek Doskonalenia Nauczycieli, s. 40-50. 